\title{
PENYULUHAN TEKNIK PERBANYAKAN TANAMAN DAN PENGENDALIAN HAMA LALAT BUAH PADA PETANI HORTIKULTURA DI KELOMPOK TANI MAPAN SEJAHTERA KOTA TARAKAN
}

\author{
Abdul Rahim 1), Adi Sutrisno1), Margiyono1) \\ 1) Fakultas Pertanian Universits Borneo Tarakan \\ 2) Fakultas Ekonomi Universitas Borneo Tarakan \\ Jl. Amal Lama No 1, Tarakan, Kalimantan Utara \\ email: rahim@borneo.ac.id
}

\begin{abstract}
The services activity was conducted counseling of plant propagation techniques and control of fruit fly pests on horticultural crops, especially fruit plants. The methods used in the service activities are lectures, discussions, field practice, evaluation, and publication of the results of counseling. The results were showed: (1) increasing farmers' insights on plant propagation techniques, and (2) pest control on horticultural crops, especially fruit flies. The activity had an impact on improving the skills of farmers, especially the propagation techniques of fruit plants. Also, horticultural farmers have alternative business skills that are economically valuable. The farmers also have been the skill to control fruit fly pests, especially in horticultural farmers (fruit planting) groups.
\end{abstract}

Key Word: Penyuluhan, Petani, Hortikultura, Perbanyakan Tanaman, Lalat Buah.

\section{PENDAHULUAN}

Kota Tarakan sebagai pusat perdagangan dan jasa di wilayah Kalimantan Utara. memiliki tantangan dalam rangka mengantisipasi permintaan komoditas tanaman hortikultura yang semakin semakin meningkat seiring dengan bertambahnya jumlah penduduk dan semakin berkurangnya lahan pertanian. Masuknya produk tanaman hortikultura, khususnya buah-buahan dari daerah lain, terutama dari negara Malaysia, mempengaruhi harga dan melemahnya minat dalam usaha budidaya tanaman buah di kota Tarakan. Sehingga, menurunkan produksi hasil yang terkait dengan usaha budidaya tanaman hortikultura, khususnya tanaman buah-buahan.

Berdasarkan homogenitas dan spesifikasi wilayah, Kota Tarakan dapat diklasifikasikan sebagai wilayah pesisir dengan luas wilayah seluruhnya mencapai 65.733 ha, yang terdiri atas daratan 250,80 ha dan luas perairan 40.653 ha (BPS, 2016). Saat ini, pusat kegiatan usaha budidaya tanaman Hortikultura, khususnya buah-buahan berdasarkan hasil observasi dan wawancara Petugas Penyuluh Pertanian (PPL) Wilayah Kerja Penyuluh Pertanian (WKPP) Kota Tarakan berada di Kecamatan Tarakan Timur, serta berdasarkan data statistik sayuram dan buahbuahan (BPS 2016) menunjukkan; (1) tanaman buah-buahan merupakan komoditas tertinggi 
kedua setelah tanaman sayur-sayuran, dan (2) memiliki luas tanam dan luas panen tertinggi dibandingkan dengan usaha budidaya tanaman lainnya.

Kelurahan Mamburungan, merupakan kelurahan di Kota Tarakan dengan luas wilayah 1.890 ha, dengan jumlah kepala keluarga 2.248 (6.970 jiwa) (LPPM, 2014). Bagian utara kelurahan ini berbatasan dengan Laut Sulawesi dan di selatan berbatasan dengan Selat Balingau, sedangkan di sebelah barat dan timur, berbatasan dengan Kelurahan Kampung IV dan Mamburungan Timur. Wilayah Mamburungan, dahulu dikenal sebagai masyarakat petani dan nelayan, namun saat ini, hanya sebagian kecil dari masyarakatnya yang memiliki mata pencaharian sebagai Petani (108 Jiwa), dengan produk yang terkenal saat itu yakni Salak Mamburungan (Salak Kota Tarakan). Usaha budidaya tanaman hortikultura, khususnya tanaman buah mengalami penurunan, ditandai dengan berkurangnya lahan pertanian, dan beralihnya masyarakat menjadi karyawan swasta (LPPM, 2014).

Khusus tanaman buah-buahan, data pada Tahun 2012 menunjukkan tanaman buah-buahan tertinggi di wilayah Kecamatan Tarakan Timur (BPS, 2012), dan hasil observasi menunjukkan bahwa pusat kegiatannya berada di Wilayah Kerja Penyuluh Pertanian (WKPP) Kelurahan Mamburungan Kecamatan Tarakan Timur, yakni tanaman Salak, Jeruk, Rambutan, dan lain sebagainya. Namun, pada tahun 2016, produksi budidaya tanaman buah-buahan dari WKPP Kelurahan Mamburungan Kecamatan Tarakan Timur mengalami penurunan hingga mencapai mencapai 35 - 60\%.

Beberapa kendala yang dihadapi yakni berkurangnya minat petani dalam mengembangkan usaha budidaya tanaman hortikultura yang disebabkan oleh; (1) kurangnya informasi tambahan pengetahuan bagi usaha alternatif terkait tanaman buah; dan (2) gangguan serangan organisme penggangu tanaman (misalnya lalat buah).

Tujuan kegiatan pengabdian ini adalah meningkatkan keterampilan/wawasan di petani hortikultura. Selain itu, memperoleh produk dari kegiatan pengabdian yakni bibit hasil teknik perbanyakan tanaman dan perangkat sederhana pengendalian hama lalat buah. Serta, memberi dampak pada peningkatan atensi terhadap salah satu alternatif usaha bagi kelompok tani hortikultura, khusunya penyediaan bibit, melalui penyuluhan teknik perbanyakan tanaman. 
ISSN : $2620-4665$ (print)

ISSN : 2620 - 4673 (online)

Website : http://jurnal.untan.ac.id/index.php/JPLP2KM

\section{METODE}

\subsection{Lokasi dan Sasaran Kegiatan Pengabdian}

Kelompok Tani Mapan Sejahtera, khusunya petani tanaman buah-buahan, dengan jumlah anggota sebanyak 38 orang, yang beralamat di RT 07 Kelurahan Mamburungan Kota Tarakan.

\subsection{Metode Kegiatan}

Metode kegiatan penyuluhan dan pendampingan adalah dengan cara ceramah, diskusi, praktek lapangan, dan evaluasi hasil praktek (Van den Ban \& Hawkins, 1999). Penyuluhan melibatkan anggota kelompok tani untuk meningkatkan pemahaman (wawasan) tentang teknik perbanyakan tanaman dan pengendalian hama tanaman, khususunya lalat buah.

Kelompok tani dalam kegiatan ini berperan sebagai subjek atau pelaku baik dalam kegiatan penyuluhan, khususnya pada saat praktek lapangan. Selain itu, semua aktivitas melibatkan penyuluh atau pendamping sebagai mitra kegiatan. Serta, kegiatan ini melibatkan mahasiswa sebagai bentuk dari pembinaan mahasiswa, khususnya mahasiswa Fakultas Pertanian Universitas Borneo.

\section{HASIL DAN PEMBAHASAN}

Kegiatan yang telah dilaksanakan yakni penyuluhan tentang; (1) teknik perbanyakan tanaman buah, dan (2) pengendalian hama lalat buah.

\subsection{Penyuluhan Teknik Perbanyakan Tanaman Buah}

Tahap awal kegiatan dengan melakukan penjelasan tentang pentingnya teknik perbanyakan tanaman dan pengendalian hama lalat buah pada petani. Materi ini disampaikan melalui diskusi bersama peserta kegiatan. Selanjutnya, dilakukan diskusi tentang upaya pengembangan pengembangan produk hortikultura, khususnya tanaman buah di kelompok tani mapan sejahtera kota Tarakan. Pada diskusi ini, narasumber selain dari akademisi, juga mengundang petani sukses dibidang perbanyakan tanaman buah untuk berbagi pengalaman tentang usaha dibidang perbanyakan tanaman (Gambar 1). Menurut Euriga, dkk (2018) kompetensi penyuluh sangat mempengaruhi efektivitas implementasi penyuluhan hortikultura berkelanjutan. 
Hasil yang diperoleh yakni meningkatnya keinginan petani untuk mengembangkan usaha perbanyakan tanaman. Indikator keberhasilan metode ceramah dan diskusi tersebut berdasarkan banyaknya aktivitas peserta, seperti bertanya, mencatat, dan berdiskusi. Selain itu, gestur tubuh peserta dalam mengikuti kegiatan menujukkan minat terhadap isi ceramah dan diskusi. Gestur diketahui memberikan rangsangan untuk menstimulasi aktivitas, dan selanjutnya mempengaruhi kualitas isi dari aktivitas tersebut (Alibali \& Kita, 2010).
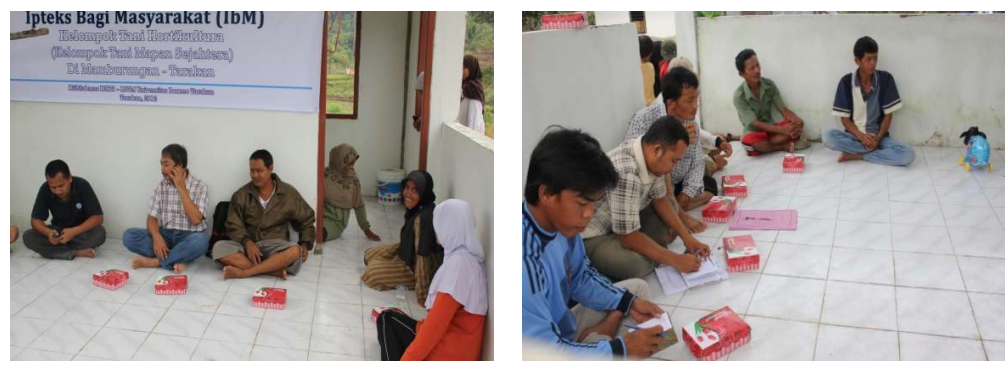

Gambar 1. Penyuluhan/Penyampaian materi kegiatan kepada petani, dan pendamping Kelompok Tani Mapan Sejahtera

Tahap selanjutnya, materi praktek dan pendampingan teknik perbanyakan tanaman yakni cangkok, teknik sambung, dan teknik lainnya. Petani diberikan contoh oleh pendamping, dan selanjutnya diberikan bahan tanam dan perlengkapan lainnya untuk melakukan praktek. Petani juga diberikan kesempatan untuk mencoba beberapa kali (Gambar 2).
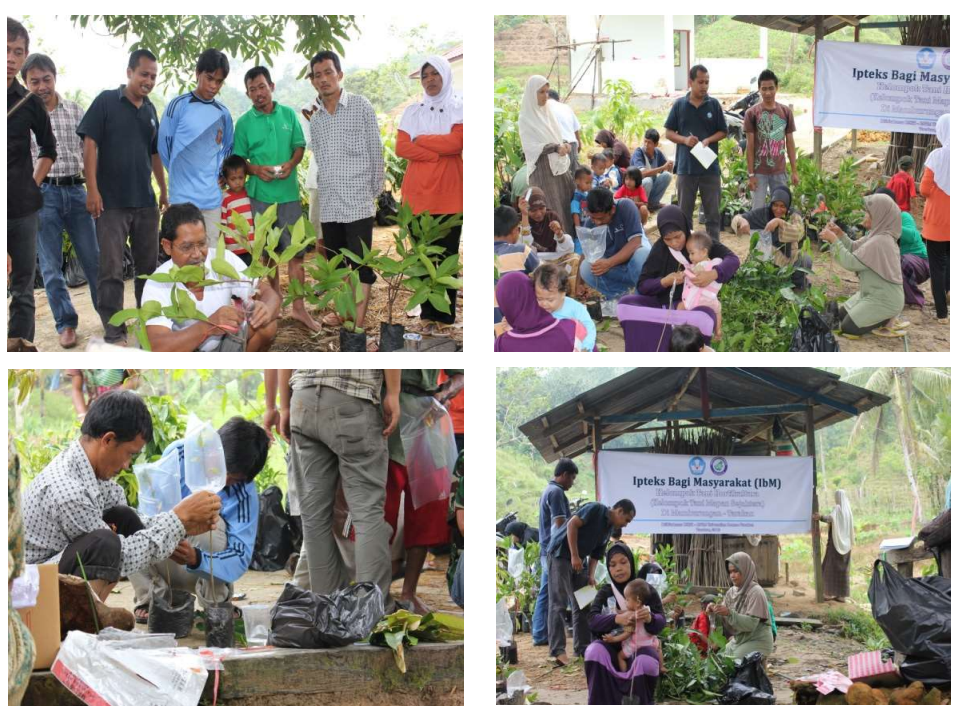

Gambar 2 Petani melakukan praktek dan hasil praktek yang di lakukan petani kelompok Tani Mapan Sejahtera. 
ISSN : $2620-4665$ (print)

ISSN : $2620-4673$ (online)

Website : http://jurnal.untan.ac.id/index.php/JPLP2KM

Pada kegiatan ini petani sangat antusias melakukan praktek. Peserta menghasilkan bibit tanaman buah dengan berbagai teknik perbanyakan. Hasil menunjukkan teknik perbanyakan dengan grafting atau menyambung lebih disenangi oleh peserta penyuluhan (Gambar 3). Selain itu, diduga peserta yang didominasi oleh ibu rumah tangga yang merupakan istri dari petani menjadi salah satu faktor penyebabnya.

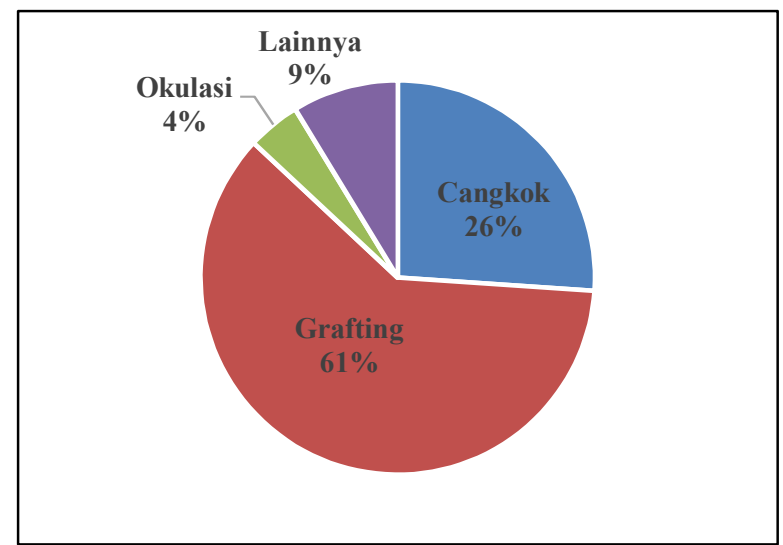

Gambar 3. Persentase bibit yang dihasilkan berdasarkan teknik perbanyakan.

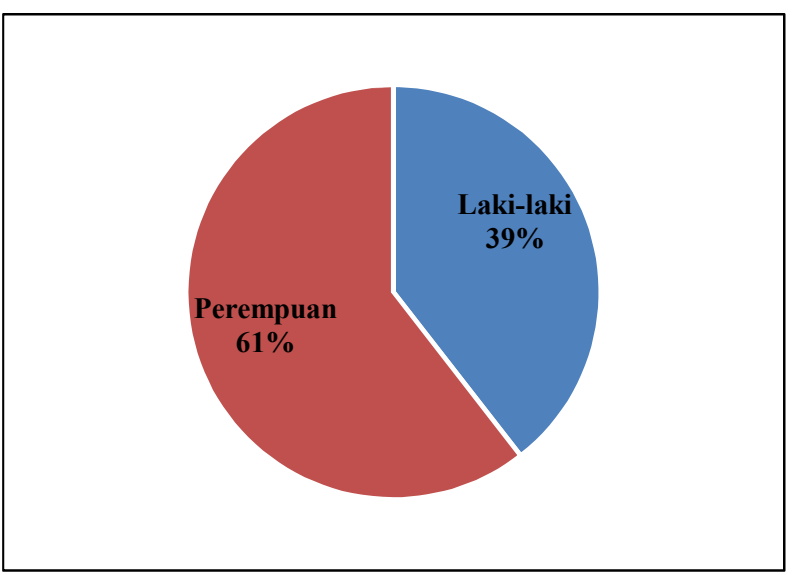

Gambar 4. Persentase jumlah peserta penyuluhan berdasarkan jenis kelamin.

Tingginya partisipasi perempuan dibandingkan dengan laki-laki (Gambar 4) memberi dampak positif bagi meningkatnya wawasan dan keterampilan ibu rumah tangga khususnya teknik perbanyakan tanaman. Akhirnya, memberi kesempatan atau peluang bagi pengembangan usaha alternatif rumah tangga yang bernilai ekonomis. 


\subsection{Penyuluhan Pengendalian Lalat Buah}

Materi praktek dan pendampingan pengendalian hama lalat buah. Pada pelatihan ini diperkenalkan dua metode sederhana yakni penggunaan senyawa methyl eugenol dengan perangkap botol dan perangkap kuning (Gambar 5). Selanjutnya, bersama petani melakukan pemasangan perangkap pada titik-titik lokasi yang telah ditentukan berdasarkan hasil pengamatan hama lalat buah sebelumnya.
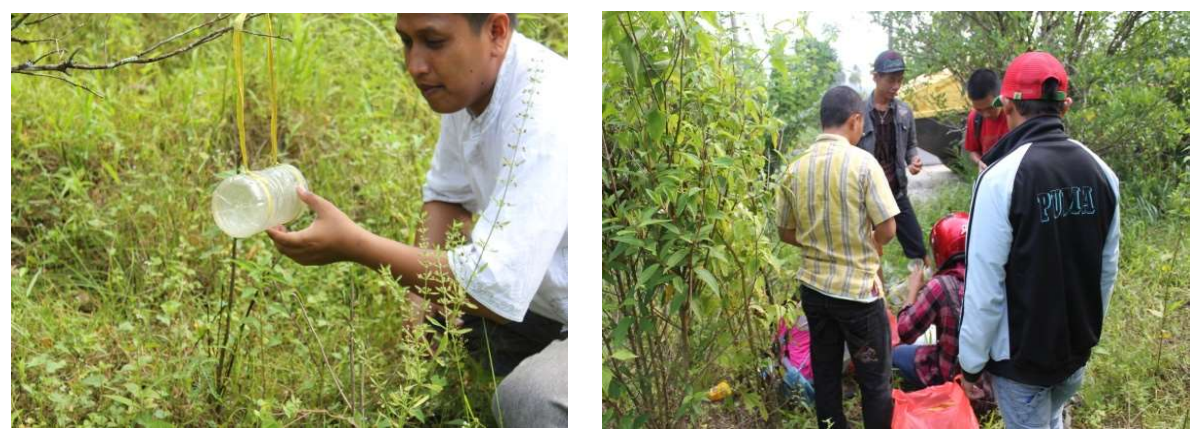

Gambar 5. Praktek pemasangan perangkap lalat buah.

Pada kegiatan ini petani mendapatkan pengalaman menggunakan dan membandingkan dua model perangkap sebagai pengendali hama lalat buah. Selain itu, peserta mengetahui jenis pemanfaatan senyawa methyl eugenol dengan perangkap botol plastik lebih efektif dibandingkan dengan penggunaan perangkap kuning.

\subsection{Tahap Evaluasi dan Publikasi}

Tahap selanjutnya yakni melakukan evaluasi hasil kegiatan melalui kunjungankunjungan ke peserta yang mengikuti kegiatan. Selanjutnya, melakukan publikasi melalui media massa dalam rangka memasyarakatkan pengetahuan tentang pentingya perbanyakan tanaman, misalnya melalui surat kabar harian lokal. Serta publikasi lainnya, misalnya melalui poster, seminar, dan bentuk-bentuk lainnya yang disusun oleh tim ipteks bagi masyarakat (lbM). 
ISSN : $2620-4665$ (print)

ISSN : 2620 - 4673 (online)

Website : http://jurnal.untan.ac.id/index.php/JPLP2KM

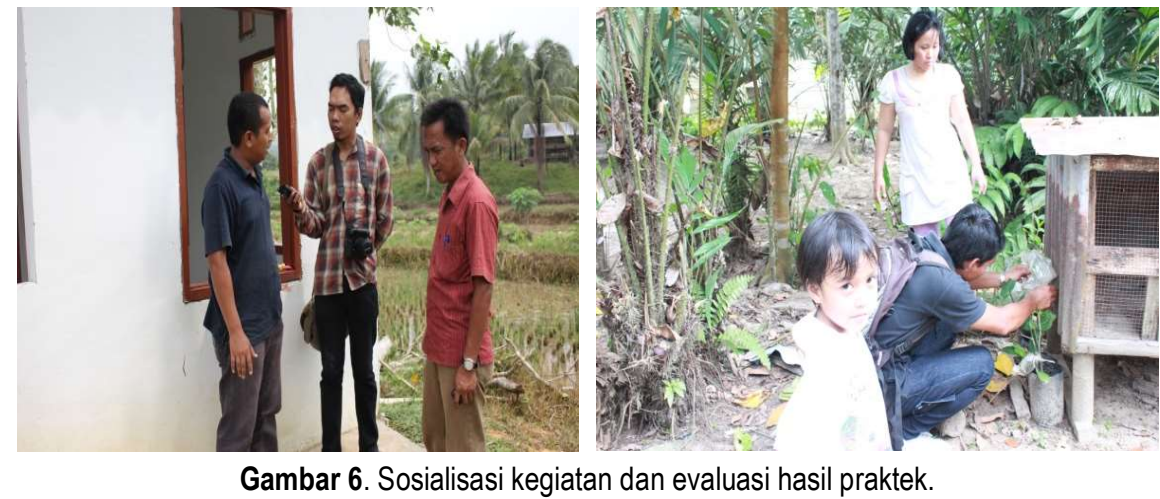

Hasil evaluasi menunjukkan peserta tertarik untuk memanfaatkan pengetahuan tentang perbanyakan sebagai alternatif usaha, namun pendampingan dalam hal pemasaran produk dan hubungan dengan pasar masih perlu ditingkatkan. Selain itu, mutu bibit perlu disesuaikan dengan keinginan pasar atau konsumen. Sedangkan, untuk pengendalian hama lalat buah, petani dengan mudah menggunakan teknik pengendalian ini dikarenakan mudahnya peralatan yang digunakan, namun ketersediaan senyawa methyl eugenol masih perlu dikembangkan dengan mencari alternatif pengganti senyawa tersebut.

\section{KESIMPULAN DAN SARAN}

\subsection{Kesimpulan}

Kesimpulan pada kegiatan pengabdian yakni kelompok Tani Mapan Sejahtera telah memiliki keterampilan dalam perbanyakan tanaman buah. Serta, pengendalian hama lalat buah. Teknik perbanyakan merupakan peluang usaha bagi petani dalam mengembangkan usaha budidaya hortikultura, khususnya penyediaan bibit tanaman buah.

\subsection{Saran}

Melakukan pembinaan secara berkelanjutan dengan melakukan upaya perbaikan mutu bibit tanaman melalui sertifikasi produk dan membantu pemasaran produk tersebut. Selain itu, perlu alternatif bahan alami lokal sebagai pengganti senyawa methyl eugenol sebagai pengendali hama lalat buah. 


\section{UCAPAN TERIMA KASIH}

Penulis mengucapkan terimakasih kepada Direktorat Penelitian dan Pengabdian kepada Masyarakat Dikti yang berkenan memberikan Hibah Ipteks Bagi Masyarakat. Serta, Rektor Universitas Borneo Tarakan, Ketua LPPM Universitas Borneo, Dekan Fakultas Pertanian, Dekan Fakultas Ekonomi Universitas Borneo, Pendamping CSR PT. Medco E\&P, Bapak Purwo sekeluarga, Ketua Kelompok Tani Mapan Sejahtera beserta seluruh anggota yang turut serta mendukung pelaksanaan kegiatan pengabdian ini.

\section{DAFTAR PUSTAKA}

Alibali, M.W., \& Kita, S. (2010). Gesture highlights perceptually present information for speakers. Gesture, 10(1); 3-28.

[BPS Tarakan] Badan Pusat Statistik Kota Tarakan. 2012. Kota Tarakan dalam Angka. BPS Tarakan.

[BPS Tarakan] Badan Pusat Statistik Kota Tarakan. 2014. Kota Tarakan dalam Angka. BPS Tarakan.

[BPS Tarakan] Badan Pusat Statistik Kota Tarakan. 2016. Statistik Sayuran dan Buah-Buahan Kota Tarakan. BPS Tarakan.

Euriga, E., S Amanah., A Fatchiya., P.S. Asngari. 2018. Implementasi Penyuluhan Hortikultura Berkelanjutan di Provinsi D.I. Yogyakarta. Jurnal Penyuluhan, 14(2).

[LPPM UBT] Lembaga Penelitian dan Pengabdian Kepada Masyarakat. 2014. Laporan KKN Desa Mamburangan Kota Tarakan. UBT Tarakan.

Van den Ban., AW, Hawkins HS. 1999. Penyuluhan Pertanian. Kanisius. Yogyakarta. 